\title{
Loss of desiccation tolerance in Copaifera langsdorffii Desf. seeds during germination
}

\author{
Pereira, WVS. ${ }^{a}$, Faria, JMR. ${ }^{a}$, Tonetti, OAO. ${ }^{a}$ and Silva, EAA. ${ }^{b}$

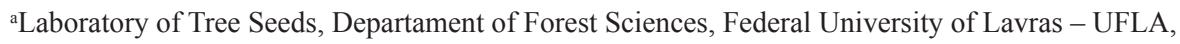 \\ CP 3037, CEP 37200-000, Lavras, MG, Brazil

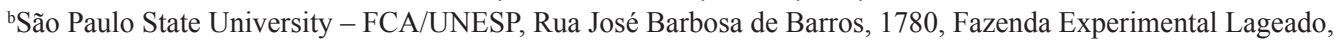 \\ CEP 18610-307, Botucatu, SP. Brazil \\ *e-mail: wvicentesp@yahoo.com.br
}

Received September 13, 2012 - Accepted January 29, 2013 - Distributed May 31, 2014

(With 3 figures)

\begin{abstract}
This study evaluated the loss of desiccation tolerance in C. langsdorffii seeds during the germination process. Seeds were imbibed for 24, 48, 72, 96, 120 and 144 hours and dried to the initial moisture content, kept in this state for 3 days after which they were submitted to pre-humidification and rehydration. Ultraestructural evaluations were done aiming to observe the cell damage caused by the dry process. Desiccation tolerance was evaluated in terms of the percentage of normal seedlings. Seeds not submitted to the drying process presented $61 \%$ of normal seedlings, and after 24 hours of imbibition, followed by drying, the seeds presented the same percentage of survival. However, after 48 hours of imbibition, seeds started to lose the desiccation tolerance. There was twenty six percent of normal seedlings formed from seeds imbibed for 96 hours and later dried and rehydrated. Only $5 \%$ of seeds imbibed for 144 hours, dried and rehydrated formed normal seedlings. At 144 hours of imbibition followed the dry process, there was damage into the cell structure, indicating that the seeds were unable to keep the cell structure during the drying process. Copaifera langsdorffii seeds loses the desiccation tolerance at the start of Phase 2 of imbibition.
\end{abstract}

Keywords: Copaíba, desiccation sensitivity, imbibition.

\section{Perda da tolerância à dessecação em sementes de Copaifera langsdorffii durante a germinação}

\section{Resumo}

Este estudo avaliou a perda da tolerância à dessecação em sementes de C. langsdorffii durante o processo germinativo. Sementes foram embebidas por 24, 48, 72, 96, 120 e 144 horas e depois secas até a umidade inicial, sendo mantidas neste estado durante 3 dias, quando então foram submetidas a pré-umidificação e reidratação. Avaliações ultraestruturais foram realizadas objetivando observar danos nas células causados pelo processo de secagem. A tolerância à dessecação foi avaliada pelo percentual de plântulas normais. Sementes não submetidas ao processo de secagem apresentaram $61 \%$ de plântulas normais, sendo que após 24 horas de embebição seguida de secagem, houve o mesmo percentual de sobrevivência. Contudo, após 48 horas de embebição, as sementes começaram a perder a tolerância à dessecação. Vinte e seis por cento de sementes formaram plântulas normais após embeberem por 96 horas e secas. Apenas $5 \%$ de sementes embebidas por 144 horas e secas formaram plântulas normais. Após 144 horas de embebição, seguida de secagem, verificou-se danos na estrutura celular, o que indica que as sementes não são capazes de manter a estrutura celular durante o processo de secagem. Verificou-se no presente estudo que sementes de C. langsdorffii perdem a tolerância à dessecação no inicio da fase 2 da embebição.

Palavras-chave: Copaíba, sensibilidade à dessecação, embebição.

\section{Introduction}

The term seed desiccation tolerance, is defined as the tolerance to conditions of low water availability (Marcos Filho, 2005) or ability to germinate after fast drying (Golovina et al., 2001). The capacity to tolerate drying occurs in the most varied types of organisms, and in the plant species it is more common in seeds, pollen grains

and spores, being able to happen in some plants in the vegetative state (Alpert, 2005). Seeds tolerant to desiccation (orthodox) acquire that capacity during their maturation process (Bewley and Black, 1994), the moment of the loss of this capacity being quite variable among the species or even among different lots of a same species. 
The desiccation tolerance mechanisms are, in general, related to the maintenance of the cell structure integrity, not only during drying, but also during imbibition, because the water uptake can also cause damage to the cell structure (Corbineau et al., 2004; Pammenter and Berjak, 1999). The mechanisms are usually related to protein and oligosaccharide synthesis that maintains the cellular structure during the dehydrated state (Barbedo and Bilia, 1998) such as the LEA proteins (late embryogenesis abundant), synthesised at the end of seed development, and suggested to be related not only to desiccation tolerance, but also the other stress types (Alpert, 2005; Bartels, 2005; Black et al., 1999; Hoekstra et al., 2001; Tunacliffe and Wise, 2007). In desiccation-sensitive seeds, theses mechanisms are abscent or appear incomplete, resulting in an insufficient accumulation of protective molecules, leading to cell susceptibility to damage from drying (Kermode and Finch-Savage, 2002; Pammenter and Berjak, 1999).

The desiccation sensitivity is associated with high metabolic rate, that is linked to the consumption of reservations and the cell cycle (Farrant et al, 1988). During the germinative process many physiological, cellular and molecular processes occur in the orthodox cell seeds that are similar those is linked to the desiccation sensitivity in recalcitrant seeds (Castro et al, 2004; Bruggink and Van Der Toorn, 1995). The injuries caused by drying (both in recalcitrant and orthodox seeds) is related to free radicals generating oxidative damage. Both recalcitrant and orthodox germinated seeds presents subcellular development and vacuolation (linked to the active metabolism), and the damage caused by drying is similar in recalcitrant and germinated orthodox seeds (Farrant et al, 1988).

A considerable number of plant species of interest bear desiccation sensitive seeds (Berjak and Pammenter, 2001; Hong and Ellis, 1996; Tweddle et al., 2003), so the understanding of the desiccation sensitivity is of great importance the establishment of seed conservation strategies (Bovi et al., 2004). However, desiccation sensitive (recalcitrant) seeds have low availability throughout the year and cannot be stored, which hinders the study of the desiccation sensitivity in these species. Thus, considering that germinating orthodox seeds presents a behaviour comparable with recalcitrant seeds, Sun (1999) proposed that germinating orthodox seeds can be useful in desiccation sensitivity studies, and the availability and storability enables its use.

Copaifera langsdorffii Desf. is the most important representative of the Copaifera genus in Brazil, given its wide geographical distribution (Andrade Junior and Ferraz, 2000; Lorenzi, 2000). The species raises interest for the medicinal application of the oil extracted from its trunk (Veiga Junior et al., 2007), besides the use of its wood in building, furniture making, lathed pieces, floorboards and other items such as tool and broom handles and weapon gunstocks (Guerra et al., 2006; Lorenzi, 2000; Veiga Junior and Pinto, 2002). Furthermore, the species is widely used in rural and urban forestation projects (Jeller and Perez, 1997) and in the recovery of degraded areas (Lorenzi, 2000).
C. langsdorffii seeds present physiological dormancy caused by the presence of germination inhibitors (Lima et al., 2006), besides coat imposed dormancy (Fowler and Bianchetti, 2000). The most common treatments for germination are the immersion in water for 96 hours, stratification for 15 days (Borges et al., 1982; Fowler and Bianchetti, 2000), immersion in ether for 20 minutes (Perez and Prado, 1993) and mechanical scarification (Fowler and Bianchetti, 2000).

C. langsdorffii seeds present orthodox behaviour, which makes them useful for studies related to desiccation tolerance and sensitivity, and it is expected that these seeds lose the desiccation tolerance around the start of phase 3 of imbibition (visible radicle protusion). Therefore, the objective of this research was to characterise the loss of desiccation tolerance in $C$. langsdorffii seeds during the germinative process.

\section{Material and Methods}

The experiments were carried out at the Laboratory of Tree Seeds of the Federal University of Lavras, MG, with seeds collected in August 2009 and stored until February 2010. Seeds were collected in a native population of Copaifera langsdorffii near Lavras, $\mathrm{MG}\left(21^{\circ} 16^{\prime} \mathrm{S} ; 45^{\circ} 02^{\prime} \mathrm{W}\right.$, altitude $911 \mathrm{~m}$ ). The initial seed moisture content was $17 \%$ and after drying the seeds in an acclimatised room $\left(20^{\circ} \mathrm{C}\right.$ $50 \%$ UR), it dropped to $11.27 \%$. Seeds were stored in a cold chamber at $5^{\circ} \mathrm{C}$ and $40 \% \mathrm{RH}$ until the beginning of the experiments and showed no variation in moisture content during the storage.

In all tests, the seeds were submitted to mechanical scarification with sandpaper. The imbibition curve of the seeds was established using 20 repetitions of 1 seed that were maintained in paper rolls and conditioned in an incubator at $25^{\circ} \mathrm{C}$ under constant light, weighing at regular intervals for up to 3 days after the protrusion of the radicle (visible germination).

Germination tests were done with 4 replicates of 25 seeds. For evaluation of the desiccation tolerance, seeds previously submitted to the mechanical scarification treatment were maintained in a paper roll in an incubator at $25^{\circ} \mathrm{C}$ under constant light. After $24,48,72,96,120$ and 144 hours of imbibition, the seed moisture content was evaluated, by drying them in an oven at $103^{\circ} \mathrm{C}$ for $17 \mathrm{~h}$ (Brasil, 2009). For each imbibition time, using the formula proposed by Hong and Ellis (1996), the target weight was determined, until the seeds reached the initial moisture content (11.27\%, see Table 1). After this, seeds were dried in a gerbox containing $120 \mathrm{ml}$ of silica gel until the target weight was reached. Moisture content was determined to confirm if the initial moisture content was reached.

After the initial moisture content had been reached, seeds remained in the gerbox for 72 hours. After this, seeds were pre-humidified at $100 \% \mathrm{RH}$ and constant light for 24 hours, and returned to the same initial germination conditions. As control, a sample of seeds of the same mechanically scarified lot (sandpaper) not submitted to the 
Table 1. Germination speed index of Copaifera langsdorffii seeds submitted to drying.

\begin{tabular}{cccc}
\hline \multirow{2}{*}{ Time } & Moisture $(\%) * *$ & \multicolumn{2}{c}{ Germination Speed Index } \\
\cline { 3 - 4 } & 11.27 & $1.53 \mathrm{a}$ & Deviation \\
\hline 24 & 32.85 & $1.78 \mathrm{a}$ & 0.09 \\
48 & 49.07 & $2.21 \mathrm{a}$ & 0.11 \\
72 & 49.64 & $1.69 \mathrm{a}$ & 0.11 \\
96 & 53.50 & $1.18 \mathrm{ab}$ & 0.02 \\
120 & 54.64 & $0.36 \mathrm{~b}$ & 0.12 \\
144 & 56.77 & $0.20 \mathrm{~b}$ & 0.07 \\
& & & $8.17 \times 10^{-7}$ \\
\hline
\end{tabular}

Same letters indicate no differences between means by Tukey test at 5\% probability. *Values for initial germination test (control). **Moisture content evaluated after the time of imbibition.

desiccation/rehydration process previously mentioned was used. Germination (1 $\mathrm{mm}$ protruded radicle) was scored daily for the calculation of germination speed index using the method proposed by Maguire (1962). Together with final germination and normal seedlings percentage, this data was used to evaluate the loss of desiccation tolerance in seeds.

Ultrastructural analyses were carried out seeking to verify possible damage caused by the desiccation/ rehydration process in $C$. langsdorffii seeds. The material for analysis was collected starting from fresh seeds at 24, 48, 72, 96, 120 and 144 hours after imbibition. These points were appraised after the imbibition, drying back to the initial moisture content and after pre-humidification. The ultrastructural evaluations were conducted at the Electron Microscopy Laboratory of the Department of Phytopathology of UFLA using the laboratory methods (Alves, 2004).

The evaluations were carried out on the embryonic axis, using the scanning electronic microscope (SEM LEO EVO 40 XVP), preparing the samples according to Alves (2004). The samples were fixed in Karnovsky fixative $(2.5 \%$ glutaraldehyde; $2.5 \%$ formaldehyde and sodium cacodylate buffer $0.05 \mathrm{M}, \mathrm{pH} 7.2, \mathrm{CaCl}_{2} 0.001 \mathrm{M}$ ) for 24 hours. After that, the samples were immersed in $30 \%$ glycerol for $30 \mathrm{~min}$, later washing in distilled water (two times of $15 \mathrm{~min}$ ). Cryofracture consisted of immersion of the samples in liquid nitrogen and cutting using a scalpel blade. Later, samples were dehydrated in acetone at a concentration gradient $(25,50,75$ and $100 \%$ 3 times). The dehydrated samples were submitted to drying in a Bal-Tec critical point apparatus.

The samples were finally mounted on stubs, conducting the metallisation (gold) and their subsequent visualisation. Images were taken and used for the comparison of the results.

The percentage data (germination and normal seedlings) were submitted to the Shapiro-Wilk test of normality. When non-normal data distribution was verified $(p<0.05)$, it were converted to the $\arcsin \sqrt{x} / 100$. After that, the data (when normalised) was submitted to the variance analysis (ANOVA) and, when difference among the treatments was verified by the $\mathrm{F}$ test, Tukey tests to $5 \%$ of probability were done. Data that did not present normal distribution, even after conversion, was analysed by the GLM (Generalised Linear Models) method through binomial distribution and, when difference among the treatments by the Chi-squared test was verified, the Tukey at $5 \%$ of probability was used. The fresh mass values of the seeds obtained in the imbibition curve evaluations were used for calculation of the mass of imbibed water over time, for making the imbibition curve of the seeds. Also a curve of desiccation tolerance loss was established during the imbibition time based on the seed survival values (expressed by germination and the percentage of normal seedlings). Using that data, the calculation of the explanatory equation for the data was made.

All analyses were conducted through the software R for Windows version 2.12.0 (R Foundation for Statistical Computing, 2010), using Microsoft Office Excel ${ }^{\circledR}$ version 2007 for graph preparation.

\section{Results}

The variation in the germination values is presented as a quadratic equation. An increase was observed in the germination percentage in seeds that were imbibed for 48 hours, being dried soon afterwards (Figure 1). The same was observed for GSI, increasing to 48 hours, declining afterwards (Table 1). Significant differences among the averages were observed, having higher germination values for seeds dried after 48 hours of imbibition (Figure 1). As for the GSI, a reduction in the values was observed when seeds with 120 and 144 hours of imbibition are dried to the initial moisture.

The incidence of normal seedlings was reduced as the imbibition time of the seeds before dehydration and rehydration increased (Figure 1). There was reduction in the percentage of normal seedlings from $61.25 \%$ (control and seeds after 24 hours of imbibition) to $5 \%$ (after 144 hours of imbibition).

Possible variations of the embryonic axis cell volume were observed during the imbibition process (Figure 2). Dry seeds (not put for imbibition) presented compact cytoplasm, with no vacuoles being observed. After 24 hours 


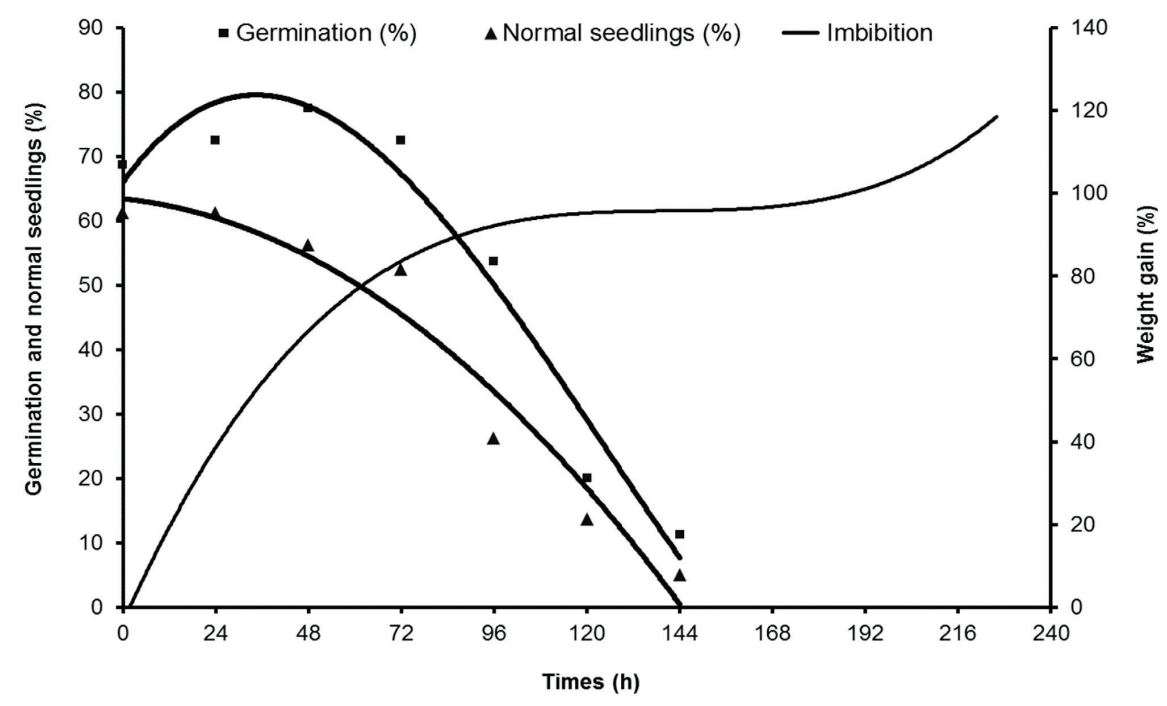

Figure 1. Loss of desiccation tolerance in Copaifera langsdorffii seeds expressed by the germination percentage and normal seedling formation during the imbibition process. Equations: Germination: $y=69.1369+0.0792 x-0.001173 x^{2}$. Normal Seedlings: $\mathrm{y}=69.136905+0.396205 \mathrm{x}-0.005865 \mathrm{x}^{2}$.

of imbibition (2B), there still were no considerable increases in the cell volume. After 120 and 144 hours of imbibition $(2 \mathrm{~F}, \mathrm{G})$, besides an increase in cell volume, we verified changes in cell morphology, comparing with the previous points, as the formation of vacuoles.

Seeds imbibed for 24 hours and dehydrated did not present damage to their cell structure (Figure 3A). Through the evaluation of the obtained images, apparent cell damage after drying and pre-humidification was not verified (Figures 3C, E).

After 144 hours of imbibition, the seeds that were submitted to drying presented damage to their cell structure and collapse, with apparent detachment of the plasmalemma from the cell wall (Figure 3B) and damage to the cell wall (Figure 3C). Furthermore, in seeds with 144 hours of imbibition submitted to drying and subsequent pre-humidification, the occurrence of cell lysis was observed (Figure 3F).

\section{Discussion}

In general, there is no occurrence of metabolic events in Phase 1 of the imbibition (Bewley and Black, 1994), and usually seeds that are at this point are capable of tolerating desiccation (Castro et al., 2004). The C. langsdorffii seeds, however, appeared to start to lose desiccation tolerance already in Phase 1 of imbibition. The accentuated decrease of the capacity to tolerate desiccation happened between 72 hours $(52.25 \%)$ and 96 hours $(26.25 \%)$. This reduction of the normal seedling percentage occurs in the beginning of Phase 2 of imbibition (96 hours), the stage where, in general, the re-activation of the cell metabolism starts.

For most of the species studied so far, desiccation tolerance in seeds is retained until slightly before or after radicle protrusion. Faria et al. (2005) verified that the desiccation tolerance in seeds of Medicago truncatula is lost only after germination. Masetto (2008) observed that Sesbania virgata germinated seeds with a $1 \mathrm{~mm}$ radicle still retained desiccation tolerance and the total loss of this capacity took place when radicles reached $2 \mathrm{~mm}$. The loss of desiccation tolerance only after radicle protrusion was also observed in Peltophorum dubium (Guimarães et al., 2011), Solanum lycopersicum and Abelmoschus esculentus (Lin et al., 1998). Oliveira (2009) observed that scarified seeds of Leucaena leucocephala lost desiccation tolerance only after radicle protrusion, differently to this study. There are no reports of seeds presenting loss of desiccation tolerance between imbibition Phases 1 and 2, whether seeds were scarified or not.

Dehydration of desiccation-sensitive tissues causes extensive damage to cell structure, among them, solute crystallisation, protein denaturation and membrane damage (Black and Pritchard, 2002). The maintenance of the cell integrity or the capacity to repair the damage caused by drying is indispensable to enable the seed to tolerate desiccation (Pammenter and Berjak, 1999). With the onset of imbibition Phase 2, when the seed water content passed $50 \%$ (Table 1), it was possible to observe a large increase in the cell volume and occurrence of vacuoles that is linked to the increase of the metabolism storage of metabolites and water and (Figures 2D-G).

After 144 hours of imbibition and subsequent drying, it was possible to observe damage to the cell structure of the seeds, which indicates that at this point the cells lose the capacity to maintain their integrity during the dehydration. This seeds presented collapse of the cells, detachment of the cell wall and cell lysis. (Figure 3B-C). These occurrences are indications that the cell structure is quite damaged due to the drying and that the seeds do not possess effective prevention or repair mechanisms 

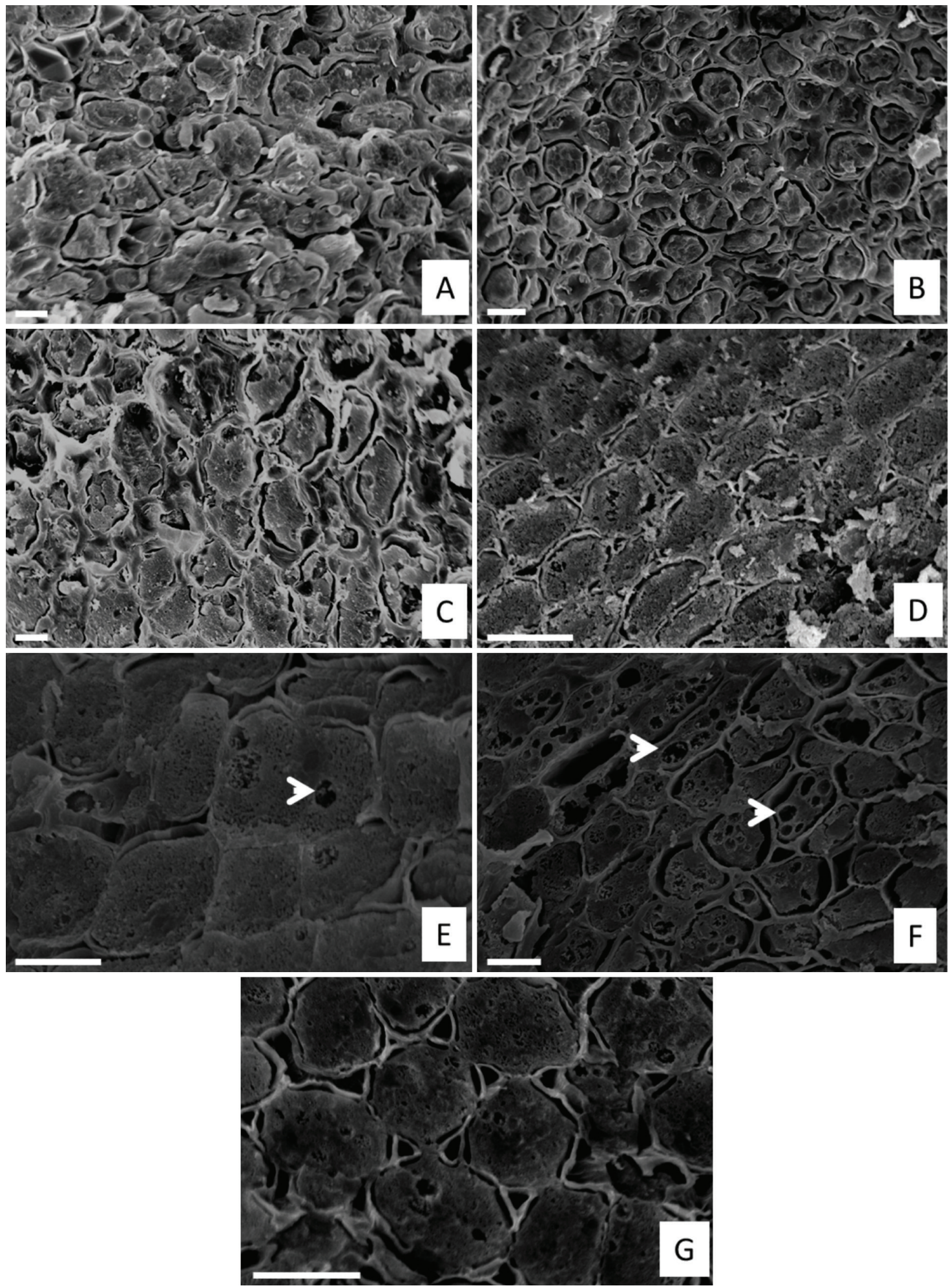

Figure 2. Scanning electron micrographs of Copaifera langsdorffi seeds during the imbibition process. (A) Fresh seed. B-G: Seeds after imbibition. (B) $24 \mathrm{~h}$ (C) 48 hours (D) 72 hours (E) 96 hours (F) 120 hours (G) 144 hours. Bars in A, C, E and $\mathrm{F}=10 \mathrm{~mm}$. Bars in $\mathrm{B}, \mathrm{D}$ and $\mathrm{G}=20 \mathrm{~mm}$. Arrows indicate cell vacuoles. 

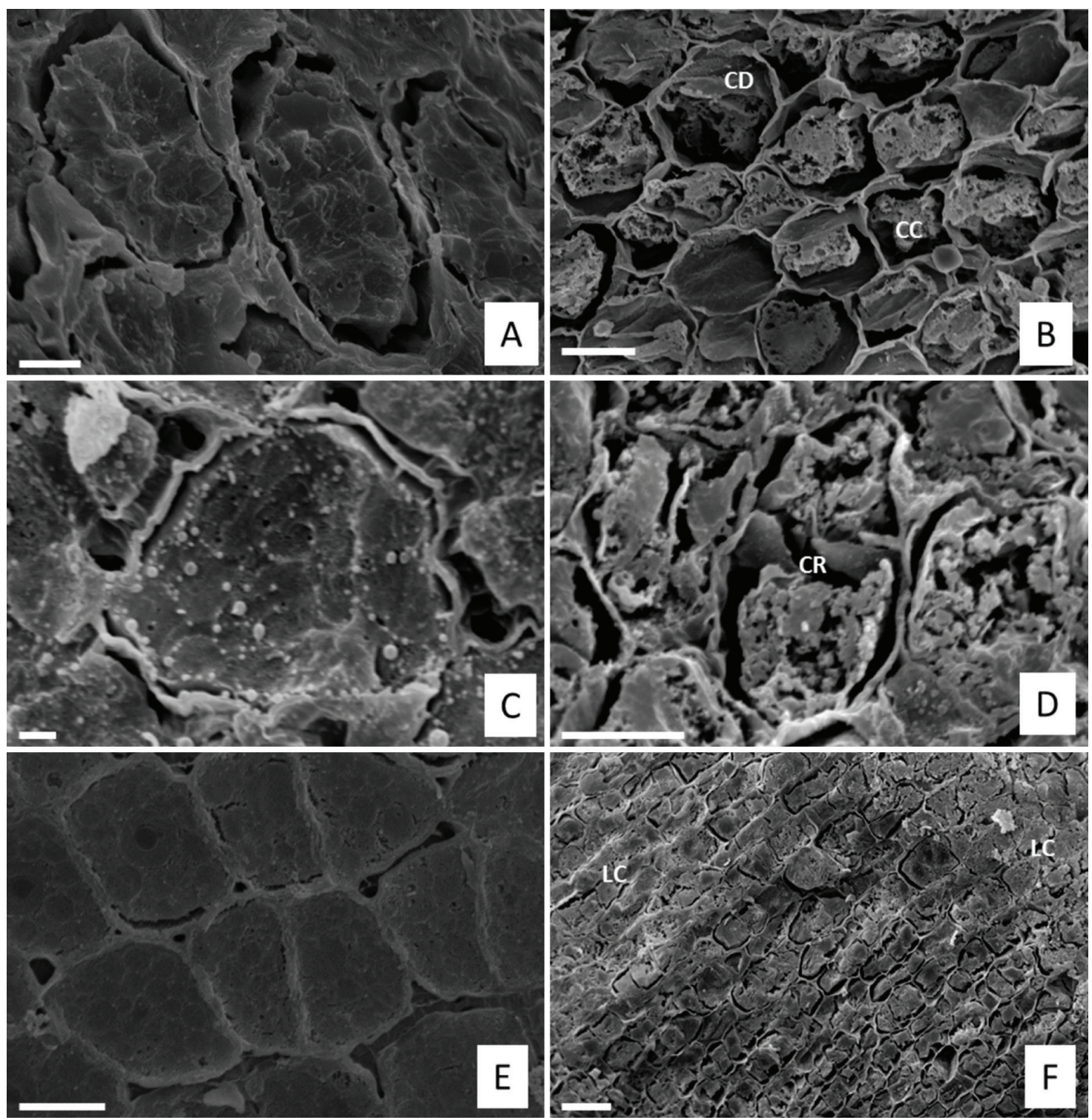

Figure 3. Scanning electron micrographs of Copaifera langsdorffii seeds. (A) After $24 \mathrm{~h}$ of imbibition. (B) After 144 hours of imbibition. (C) After $24 \mathrm{~h}$ of imbibition and drying until the initial moisture. (D) Cell wall damaged after 144 hours of imbibition and drying until the initial moisture content. (E) After $24 \mathrm{~h}$ of imbibition and drying until initial moisture remaining as is for 72 hours and pre-humidification for 24 hours. (F) After 144 hours of imbibition, drying until initial

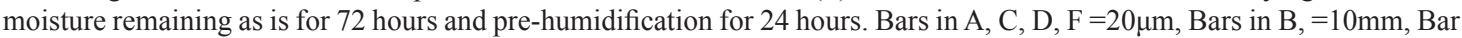
in $\mathrm{E}=1 \mathrm{~mm}$. $\mathrm{CD}=$ Cell damage $; \mathrm{CC}=$ Cell collapse $\mathrm{CR}=$ Cell wall rupture; $\mathrm{LC}=$ cell lysis.

for that damage. This can be one of the factors linked to the loss of desiccation tolerance in C. langsdorffii seeds during the germinative process.

Various authors have verified that the cell structure is irreversibly damaged with the drying of the seed during the germinative process. Guimarães et al. (2011) verified that the drying of in Peltophorum dubium germinated seeds causes complete disorganisation of the cell structure, with organelle membrane degradation and plasma membrane damage. Damage to the cell structure has also been reported in other species such as recalcitrant embryonic axes of
Trichilia emetica (Kioko et al., 2006) and orthodox seeds of Leucaena leucocephala (Oliveira, 2009). Koster and Leopold (1988) observed that one of the factors related to cell damage, especially in the membrane, is related to the reduction of the sucrose content in the seed.

\section{Conclusions}

The loss of desiccation tolerance in C. langsdorffii seeds begins in Phase 1 of imbibition, being totally lost in the middle of Phase 2. 
The cell structure of the germinating seed is damaged by desiccation.

The loss of desiccation tolerance in seeds of C. langsdorffii, at the onset of imbibition Phase 2 is an indication that seed metabolism is re-activated at the beginning of Phase 1 of imbibition.

Acknowledgements - We are grateful to the Foundation for Research Support of Minas Gerais (FAPEMIG) for providing a scholarship to W.V.S.P. And to the Laboratory of Electron Microscopy of the Federal University of Lavras. The research was carried out with support from the National Council for Scientific and Technological Development (CNPQ), process number 482015/2010-1.

\section{References}

ALPERT, P., 2005. The limits and frontiers of desiccation-tolerant life. Integrative and Comparative Biology, vol. 45, no. 5, p. 685695. http://dx.doi.org/10.1093/icb/45.5.685. PMid:21676818

ALVES, E., 2004. Apostila do curso introdutório à microscopia eletrônica de varredura. Lavras: Editora UFLA. 43 p.

ANDRADE JUNIOR, MA. and FERRAZ, IDK., 2000. Eventos fenológicos de copaíba (Copaifera officinalis L. - Caesalpinaceae) em mata de galeria do Rio Branco, Boa Vista/Roraima, Brasil: Uma primeira aproximação. Acta Amazonica, vol. 30, p. 523-533.

BARBEDO, CJ. and BILIA, DAC., 1998. Evolution of research on recalcitrant seeds. Scientia Agricola, vol. 55, no. spe, p. 121125. http://dx.doi.org/10.1590/S0103-90161998000500022.

BARTELS, D., 2005. Desiccation tolerance studied in the resurrection plant Craterostigma plantagineum. Integrative and Comparative Biology, vol. 45, no. 5, p. 696-701. http://dx.doi. org/10.1093/icb/45.5.696. PMid:21676819

BERJAK, P. and PAMMENTER, NW., 2001. Seed recalcitrance - current perspectives. South African Journal of Botany, vol. 67, p. 79-89.

BEWLEY, JD. and BLACK, M., 1994. Seeds: physiology of development and germination. Nova York: Plenum Press.

BLACK, M., CORBINEAU, F., GEE, H. and CÔME, D., 1999. Water content, raffinose, and dehydrins in the induction of desiccation tolerance in immature wheat embryos. Plant Physiology, vol. 120, no. 2, p. 463-472. http://dx.doi.org/10.1104/ pp.120.2.463. PMid:10364397

BLACK, M. and PRITCHARD, HW., 2002. Desication and survival in plants. Nova York: CABI Publishing.

BORGES, EEDL., BORGES, RDCG, CANDIDO, JF. and GOMES, JM., 1982. Comparação de métodos de quebra de dormência em sementes de copaíba. Revista Brasileira de Sementes, vol. 4, no. 1, p. 09-12.

BOVI, MLA., MARTINS, CC. and SPIERING, SH., 2004. Desidratação de sementes de quatro lotes de pupunheira: efeitos sobre a germinação e o vigor. Horticultura Brasileira, vol. 22, no. 1, p. 109-112. http://dx.doi.org/10.1590/S0102-05362004000100023.

BRASIL. Ministério da Agricultura, Pecuária e Abastecimento, 2009. Regras de análise de sementes. Brasília: MAPA/ACS. 399 p.
BRUGGINK, T. and VAN DER TOORN, P., 1995. Induction of desiccation tolerance in germinated seeds. Seed Science Research, vol. 5, no. 01, p. 1-4. http://dx.doi.org/10.1017/S096025850000252X.

CASTRO, RDD., BRADFORD, KJ. and HILHORST, HW., 2004. Embebição e reativação do metabolismo. In FERREIRA, AG. and BORGHETTI, F. Germinação: Do básico ao aplicado. Porto Alegre : Artmed. p. 149-162.

CORBINEAU, F., BERJAK, P., PAMMENTER, N., VINEL, D., PICARD, MA. and COME, D., 2004. Reversible cellular and metabolic changes induced by dehydration in desiccation-tolerant wheat seedling shoots. Physiologia Plantarum, vol. 122, no. 1, p. 28-38. http://dx.doi.org/10.1111/j.1399-3054.2004.00351.x.

FARRANT, JM., PAMMENTER, NW. and BERJAK, P., 1988. Recalcitrance - a Current Assessment. Seed Science and Technology, vol. 16, p. 155-166.

FARIA, JMR., BUITINK, J., VAN LAMMEREN, AA. and HILHORST, HWM., 2005. Changes in DNA and microtubules during loss and re-establishment of desiccation tolerance in germinating Medicago truncatula seeds. Journal of Experimental Botany, vol. 56, no. 418, p. 2119-2130. http://dx.doi.org/10.1093/ jxb/eri210. PMid:15967778

FOWLER, JAP. and BIANCHETTI, A., 2000. Dormência em sementes florestais. Colombo: Embrapa Florestas.

GOLOVINA, EA., HOEKSTRA, FA. and VAN AELST, AC., 2001. The competence to acquire cellular desiccation tolerance is independent of seed morphological development. Journal of Experimental Botany, vol. 52, no. 358, p. 1015-1027. http://dx.doi. org/10.1093/jexbot/52.358.1015. PMid:11432918

GUERRA, MEDC., MEDEIROS FILHO, S. and GALLÃO, I., 2006. Morfologia de sementes de plântulas e da germinação de Copaifera langsdorffii Desf. (Leguminosae - Caesalpinoideae). Cerne, vol. 12, p. 322-328.

GUIMARÃES, CC., FARIA, JMR., OLIVEIRA, JM. and SILVA, EAA., 2011. Avaliação da perda da tolerância à dessecação e da quantidade de DNA nuclear em sementes de Peltophorumdubium (Spreng.) Taubert durante e após a germinação. Revista Brasileira de Sementes, vol. 33, no. 2, p. 207-215. http://dx.doi.org/10.1590/ S0101-31222011000200002.

HOEKSTRA, FA., GOLOVINA, EA. and BUITINK, J., 2001. Mechanisms of plant desiccation tolerance. Trends in Plant Science, vol. 6, no. 9, p. 431-438. http://dx.doi.org/10.1016/ S1360-1385(01)02052-0. PMid:11544133

HONG, TD. and ELLIS, RH., 1996. A protocol to determine seed storage behaviour. Rome: International Plant Genetic Resources Institute. 62 p.

JELLER, H. and PEREZ, SCJGDA., 1997. Efeito da salinidade e semeadura em diferentes profundidades na viabilidade e no vigor de Copaifera langsdorffii Desf. - Caesalpiniaceae. Revista Brasileira de Sementes, vol. 19, p. 218-224.

KERMODE, AR. and FINCH-SAVAGE, BE., 2002. Desiccation Sensitivity in Orthodox and Recalcitrant Seeds in Relation to Development. In BLACK, M. and PRITCHARD, HW. (Ed.). Desiccation and survival in plants: drying without dying. Wallingford: CABI Publishing. p. 169-179.

KIOKO, JI., BERJAK, P. and PAMMENTER, NW., 2006. Viability and ultrastructural resbponses of seeds and embryonic axes of Trichilia emetic to different dehydration and storage conditions. South African Journal of Botany, vol. 72, no. 1, p. 167-176. http:// dx.doi.org/10.1016/j.sajb.2005.07.001. 
KOSTER, KL. and LEOPOLD, AC., 1988. Sugars and desiccation tolerance in seeds. Plant Physiology, vol. 88, no. 3, p. 829-832. http://dx.doi.org/10.1104/pp.88.3.829. PMid:16666392

LIN, TP., YEN, WL. and CHIEN, CT., 1998. Disappearance of desiccation tolerance of imbibed crop seeds is not associated with the decline of oligosaccharides. Journal of Experimental Botany, vol. 49, no. 324, p. 1203-1212. http://dx.doi.org/10.1093/ $\mathrm{jxb} / 49.324 .1203$.

LIMA, JAD., OLIVEIRA, MCD., SANTANA, DGD. and LUZ, JM., 2006. Maturação e inibidores de germinação na emergência de plântulas de copaíba (Copaifera langsdorffii Desf.- Caesalpiniaceae). In Proceedings of the $46^{\circ}$ Congresso Brasileiro de Olericultura, 2006. Goiânia: Associação Brasileira de Horticultura.

LORENZI, H., 2000. Árvores Brasileiras: Manual de Identificação e Cultivo de Plantas Arbóreas no Brasil. Nova Odessa: Instituto Plantarum.

MAGUIRE, JD., 1962. Speed of germination-aid in selection and evaluation for seedling emergence and vigor. Crop Science, vol. 2, no. 2, p. 176-177. http://dx.doi.org/10.2135/cropsci1962 .0011183 X000200020033x.

MARCOS FILHO, J.,2005 Sementes recalcitrantes. In MARCOS FILHO, J. (Ed.). Fisiologia de sementes de plantas cultivadas. Piracicaba: Fealq. p. 353-379.

MASETTO, TE., 2008. Reestabelecimento da tolerância à dessecação em sementes germinadas de Sesbania virginata e Cedrela fissilis. Lavras: Universidade Federal de Lavras. 92 p. Tese de doutorado.

OLIVEIRA, JMD., 2009. Perda da tolerância à dessecação em sementes de Leucaena leucocephala durante à germinação. Lavras: Universidade Federal de Lavras. 71 p. Dissertação de Mestrado.
PAMMENTER, NW. and BERJAK, P., 1999. A review of recalcitrant seed physiology in relation to desication-tolerance mechanisms. Seed Science Research, vol. 9, no. 01, p. 13-37. http://dx.doi.org/10.1017/S0960258599000033.

PEREZ, SCJGA. and PRADO, AHBA., 1993. Efeito de diferentes tratamentos pré-germinativos e da concentração de alumínio no processo germinativo de sementes de Copaifera langsdorffii Desf. Revista Brasileira de Sementes, vol. 15, p. 115-118.

R FOUNDATION FOR STATISTICAL COMPUTING, 2010. $R$ : A language and environment for statistical computing. Vienna: R Foundation for Statistical Computing.

SUN, WQ., 1999. Desiccation sensitivity of recalcitrant seeds and germinated orthodox seeds: Can germinated orthodox seeds serve as a model system for studies of recalcitrance? In MARZALINA, M., KHOO, KC., JAYANTHI, N., TSAN, FY. and KRISHIPNAPILLAY, B. (Ed.). Recalcitrant Seeds: Proceedings of the IUFRO Seed Symposium. Malaysia: Kuala Lumpur. p. 29-42.

TWEDDLE, JC., DICKIE, JB., BASKIN, CC. and BASKIN, JM., 2003. Ecological aspects of seed desiccation sensitivity. Journal of Ecology, vol. 91, no. 2, p. 294-304. http://dx.doi. org/10.1046/j.1365-2745.2003.00760.x.

VEIGA JUNIOR, VF., ANDRADE JUNIOR, MA., FERRAZ, IDK., CHRISTO, HB. and PINTO, AC., 2007. Constituintes das sementes de Copaifera officinalis L. Acta Amazonica, vol. 37, no. 1, p. 123-126. http://dx.doi.org/10.1590/S0044-59672007000100015.

TUNNACLIFFE, A. and WISE, MJ., 2007. The continuing conundrum of the LEA proteins. Naturwissenschaften, vol. 94, no. 10, p. 791-812. http://dx.doi.org/10.1007/s00114-007-0254-y. PMid:17479232

VEIGA JUNIOR, VF. and PINTO, AC., 2002. O gênero Copaifera L. Quimica Nova, vol. 25, no. 2, p. 273-286. http://dx.doi. org/10.1590/S0100-40422002000200016. 